NBER WORKING PAPER SERIES

\title{
U.S.-MEXICO INTEGRATION AND \\ REGIONAL ECONOMIES: EVIDENCE \\ FROM BORDER-CITY PAIRS
}

Gordon H. Hanson

Working Paper 5425

\section{NATIONAL BUREAU OF ECONOMIC RESEARCH \\ 1050 Massachusetts Avenue \\ Cambridge, MA 02138 \\ January 1996}

I thank Dan Hamermesh, Jim Harrigan, and seminar participants at the National Bureau of Economic Research and the University of Texas for helpful comments. Raymond Robertson provided excellent research assistance. This paper is part of NBER's research program in International Trade and Investment. Any opinions expressed are those of the author and not those of the National Bureau of Economic Research.

(C) 1996 by Gordon H. Hanson. All rights reserved. Short sections of text, not to exceed two paragraphs, may be quoted without explicit permission provided that full credit, including $(\mathcal{O}$ notice, is given to the source. 


\title{
U.S.-MEXICO INTEGRATION AND \\ REGIONAL ECONOMIES: EVIDENCE \\ FROM BORDER-CITY PAIRS
}

\begin{abstract}
In this paper, I examine whether U.S.-Mexico economic integration is causing economic activity in the United States to relocate to the U.S.-Mexico border region. The approach I take is to study U.S.-Mexico border-city pairs. Border cities are natural laboratories in which to study the effects of trade policy. To the extent transport costs are the main non-trade policy barriers to trade, we expect regional economic integration to cause economic activity in border cities to expand. I exploit the fact that U.S.-Mexico integration has effectively been underway since the early 1980s. A large portion of U.S.-Mexico trade is the result of U.S. multinationals establishing export assembly operations in Mexico. Mexico's export assembly plants are concentrated in cities on the U.S.-Mexico border. The question I ask is whether the growth of export manufacturing in Mexican border cities increases the demand for goods and services produced in neighboring U.S. border cities. I estimate demand links between Mexican and U.S. border cities using data on the six largest border-city pairs over the period 1975-1989. The results indicate that the growth of export manufacturing in Mexico can account for a substantial portion of employment growth, in general, and of manufacturing employment growth, in particular, in U.S. border cities over the sample period. This suggests that NAFTA will contribute to the formation of binational regional production centers along the U.S.-Mexico border.
\end{abstract}

Gordon H. Hanson

Department of Economics

University of Texas

Austin, TX 78712

and NBER 


\section{Introduction}

The proliferation of regional trade agreements (RTAs) has sparked renewed interest in economic integration. ${ }^{1}$ An important difference between RTAs, such as the North American Free Trade Agreement (NAFTA) and the European Union, and multilateral trade agreements, such as the General Agreement on Trade and Tariffs (GATT), is that RTAs reduce trade barriers between contiguous countries. This raises the prospect that such agreements will profoundly affect the economic geography of integrating countries. Recent theoretical literature in international trade finds that trade policy affects the size and location of cities within countries (Henderson 1982, Rauch 1989, Krugman and Venables 1990 and 1996). Krugman and Livas (1992) and Rauch (1993) show, in particular, that trade tends to shift economic activity towards regions with lowcost access to foreign markets, such as port cities or border areas. In the case of NAFTA, for instance, the physical location of Mexico and Canada imply that U.S. border regions, all else equal, have a geographic advantage in production for the North American market. Despite the importance of the topic, there has been virtually no empirical work on how economic integration affects the location of economic activity within countries. ${ }^{2}$

In this paper, I examine whether U.S.-Mexico integration is causing economic activity along the U.S. border with Mexico to expand. I exploit the fact that U.S.-Mexico integration has, in may respects, been underway for over a decade. During the 1980s, Mexico liberalized trade and substantially reduced restrictions on foreign investment (Lustig 1992). The result has been

1 See Baldwin and Venables (1995) for a survey of the literature on regional integration.

2 Curiously, the multitude of computable general equilibrium models developed to study NAFTA ignore the effects of trade on the intranational location of economic activity (see the volumes in Francois and Shiells (1994) and the surveys in Brown, Deardorff, and Stern (1992) and Lustig, Bosworth, and Lawrence (1992)). 
a dramatic increase in U.S.-Mexico trade, primarily in manufactured products. There are two channels through which U.S.-Mexico integration could shift resources from the interior United States to the U.S. border with Mexico. First, an increase in the flow of trade across the U.S.Mexico border may increase the demand for transportation and distribution services produced at the border. In this outcome, the border functions as a land port. Second, the existence of transport costs may give U.S. firms that export to Mexico or that import inputs from Mexico an incentive to locate their U.S. operations in sites with relatively low-cost access to the Mexican market. In this outcome, the border functions as a binational regional production center.

The approach I take is to study U.S.-Mexico border-city pairs. Border cities are natural laboratories in which to consider the effects of trade policy. To the extent that transport costs are the main non-trade-policy barriers to trade, we expect regional integration to cause economic activity in border cities to expand. A large fraction of U.S.-Mexico trade in manufactures is the result of U.S. multinational firms establishing export assembly operations in Mexico. Mexican export assembly plants, known as maquiladoras, import most inputs from and export most output to the United States. The plants are concentrated in Mexican border cities. The question I ask is whether the growth of export manufacturing in Mexican border cities increases the demand for goods and services produced in neighboring U.S. border cities. I estimate demand links between Mexican and U.S. border cities using annual data on the six largest border-city pairs for 19751989. Data on one-digit industries in U.S. border cities are available from the BEA and data on export manufacturing in Mexican border cities are available from Mexican government sources. My results show strong support for the hypothesis that economic integration leads to the expansion of economic activity in border regions. I find that a $10.0 \%$ increase in export 
manufacturing in a Mexican border city leads to 2.4 to $4.9 \%$ increase in manufacturing employment (and a smaller increase non-manufacturing employment) in the neighboring U.S. border city. This suggests that as NAFTA furthers the process of U.S.-Mexico integration it will cause U.S. industries to relocate towards the U.S.-Mexico border region. That regional integration contributes to a spatial reallocation of resources helps explain the nature of political support for trade agreements. Politicians from border states were much more likely to be in favor of NAFTA than were politicians from northern states. ${ }^{3}$ We expect politicians to support (oppose) an initiative that redistributes income towards (away from) their constituents. Organized labor -- including unions in industries that at the national level are expected to benefit from NAFTA -- showed unanimous opposition to NAFTA. Union workers in the midwest and northeast may be just as worried about losing jobs to Texas as they are about losing jobs to Mexico.

The remainder of the paper is organized as follows. Section II develops an empirical framework for examining how regional integration affects border economies. Section III describes the data and presents summary statistics on the U.S.-Mexico border economy. Section IV presents empirical results. And section V concludes.

\section{An Empirtcal Framework}

\section{A. Model Specification}

The industries of a city produce for local, national, and international markets. As demand for a city-industry's output expands, the city-industry draws resources from other industries within

${ }^{3}$ The NAFTA vote in the U.S. House of Representatives is illustrative. Only $35 \%$ of representatives from northeastem states and $48 \%$ of representatives from midwestern states voted for NAFTA, compared to $65 \%$ of representatives from western states and $73 \%$ of representatives from districts on the U.S.-Mexico border. ("The House Vote: A Closer Look," New York Times, November 18, 1993, p. A20). 
the city and perhaps from locations outside the city. City-industry employment can be modeled empirically as a function of local, national, and international sources of demand for city-industry output. This approach is similar in spirit to Revenga (1992) and Grossman (1987), who examine the impact of international trade on employment and wages at the national-industry level.

City-industries differ from national industries in a key respect. While a positive demand shock to city-industry output increases city-industry employment, it may have no long-run effect on city-industry wages. In a competitive labor market, a positive local labor-demand shock puts upwards pressure on local wages, attracting labor from other city-industries until wage differentials are eliminated. At the level of a city-industry, we imagine the supply of labor to be highly elastic. If the labor-demand shock is small and specific to the city-industry, it will reallocate labor across sectors and space without having a perceptible effect on wages.

The source of foreign demand for U.S. city-industry output I specify is export production located in the Mexican border city that neighbors a given U.S. border city. Border-city pairs represent natural agglomerations of economic activity. By matching U.S. and Mexican border cities, I am able to observe whether increased production for the U.S. market by Mexican manufacturers affects the level of economic activity of nearby U.S. producers. By law, Mexican export assembly plants are required to export all output. ${ }^{4}$ Since only a tiny fraction of maquiladora exports go to consumers in U.S. border cities, Mexican export production can be treated as a source of demand for inputs produced in U.S. border cities that is exogenous to consumer demand along the border. It may be, of course, that export manufacturers in Mexican border cities purchase inputs from a variety of U.S. sources. Producers in U.S. border cities,

\footnotetext{
4 Throughout the paper I use the terms export assembly plant and maquiladora interchangeably.
} 
however, represent the nearest source of foreign supply. If there are advantages to geographic proximity, which is essential for U.S.-Mexico integration to matter for industry location, I expect export production in a Mexican border city to be positively correlated with employment in the neighboring U.S. border city.

Consider a competitive labor market in which labor demand in U.S. border city $i$ by industry $j$ at time $t, L^{D}$, is given by

$$
\operatorname{lnL} D_{i j t}^{D}=x_{i j t} \Pi+Y_{i j t} \Gamma+\delta \ln \phi_{i j t}+\epsilon_{i j t}^{D}
$$

where $X_{y t}$ is a vector of observable domestic factors that shift labor demand in city-industry $i j$, $Y_{i j t}$ represents observable foreign factors that shift labor demand in $i j, W_{i j t}$ is the wage in $i j$, and $\varepsilon_{i j t}^{D}$ is an unobserved shock to labor demand. I measure $Y_{i j t}$ as $E X P_{i t}$, the level of export production in the Mexican border city that neighbors U.S. border city $i$.

Let labor supply in U.S. border city-industry $i j$ at time $t, L_{i j}^{S}$, be given by a standard labor-supply function, which is expressed as

$$
\ln L_{i j t}^{s}=p_{0}+p_{1} \ln W^{\lambda}{ }_{i j t}+p_{2} \ln W_{i j t}+\epsilon_{i j t}^{s}
$$

where $W_{i j t}^{A}$ is the alternative wage for workers in city-industry $i j$ and $\varepsilon_{i j t}^{S}$ represents an unobserved shock to labor supply. By equating labor demand and labor supply, I derive the following reduced-form regression equations for equilibrium city-industry employment and wages:

$$
\begin{aligned}
& \ln L_{i j t}=\gamma \ln \|^{A}{ }_{i j t}+x_{i j t} \alpha+\beta \ln E X P_{i t}+\eta_{i f t} \\
& \ln W_{i j t}=\lambda \ln W^{A}{ }_{i j t}+x_{i j t} \phi+\theta \ln E X P_{i t}+\mu_{i j t}
\end{aligned}
$$

where $\alpha$ and $\phi$ are vectors of parameters, $\gamma, \beta, \lambda$, and $\theta$, are scalar parameters, and the error terms, $\eta_{y, t}$ and $\mu_{i t r}$, are weighted sums of $\varepsilon_{i j t}^{D}$ and $\varepsilon_{y j r}^{s}$ 


\section{B. Estimation Issues}

The choice of estimator for equations (3) and (4) depends on the source of the error terms, $\eta_{i j t}$ and $\mu_{i j t}$. One source of error is unobserved city-industry or time-specific factors that affect labor demand and supply. The existence of a major highway that passes through one border city and not the others, for instance, may cause labor demand in that border city to be relatively high. To control for such idiosyncratic factors, I take a fixed-effects approach to estimating equations (3) and (4). I assume the error terms, $\eta_{y t}$ and $\mu_{i j}$, have the following form:

$$
\begin{aligned}
& \text { (5) } \eta_{i j t}=\tau_{t}+\omega_{i j}+\zeta_{i j t} \\
& \text { (6) } \mu_{i j t}=\kappa_{t}+\imath_{i j}+\psi_{i j t}
\end{aligned}
$$

where $\tau$, and $\kappa_{i}$ are fixed year effects, $\omega_{i j}$ and $l_{i j}$ are fixed city-industry effects, and $\zeta_{i j t}$ and $\psi_{i j}$ are i.i.d. errors with mean zero and constant variance. ${ }^{5}$ The solutions to fixed effects are to time difference the data or include dummy variables for the year and city-industry in the estimation.

An additional source of error is that the variable $\ln E X P_{i t}$ may be an imperfect measure of the foreign demand for output produced in a U.S. border city-industry. $\ln E X P_{i t}$ is actual maquiladora output. Maquiladoras make input orders for a given year based on expected output, which will only be imperfectly correlated with actual output. Measurement error in $\ln E X P_{t}$ would imply a negative correlation between the variable and the error terms, $\zeta_{3 y t}$ and $\psi_{g t}$, which would bias the coefficient estimates on $\ln E X P_{i t}$ in equations (3) and (4) towards zero (Griliches 1986). Griliches and Hausman (1986) show that time differencing the data exacerbates the bias due to measurement error, though the effect is less severe for long time differences. This would argue against time differencing to control for fixed effects. A justification for time differencing

\footnotetext{
5 An alternative to the fixed-effects assumption is that the idiosyncratic factors are random. If any of the regressors are correlated with $\zeta_{y, t}$ and $\psi_{y j,}$, as the ensuing discussion suggests, the random-effects estimator is biased.
} 
is if there is a concern that the data are non-stationary (or, more precisely, non-trend stationary).

A related concern is that $\ln E X P_{i t}$ may be an endogenous function of the other right-handside variables. Export producers that locate in a Mexican border city may choose the city based in part on the characteristics of the neighboring U.S. border city. The availability of input suppliers directly across the border in San Diego, for instance, may make Tijuana a relatively attractive site among Mexican cities in which to locate export production. In this event, labor demand and supply shocks in a U.S. border city-industry may affect export production in the neighboring Mexican border city. This is an additional manner in which $\ln E X P_{u}$ may be correlated with the error terms $\zeta_{y j t}$ and $\psi_{y, r}$ which would also introduce bias into the estimation.

To control for unobserved fixed effects, I estimate equations (3) and (4) in levels, with dummy variables for the city-industry and year included in the estimation, and in time-differenced form, with dummy variables for the year included in the estimation. To reduce the effects of measurement error in the time-difference regressions, I use long time differences of the data. To correct for correlation between $\ln E X P_{i t}$ and $\zeta_{y t}$ and $\Psi_{i j t}$ I use instrumental variables (IV) techniques. An appropriate instrument is correlated with $\ln E X P_{i t}$ and uncorrelated with the error terms. If $\zeta_{y i t}$ and $\psi_{y i}$ are not serially correlated, lagged values of $\ln E X P_{i t}$ are valid instruments. The instruments I use are the exogenous independent variables and lagged values of $\ln E X P_{i x}$.

\section{Data Description}

\section{A. Data Sources}

My sample consists of the six largest U.S. border cities and their Mexican counterparts. Table 1 describes the city pairs. Data are available from two sources. The BEA provides annual 
data on one-digit employment and earnings for U.S. metropolitan statistical areas (MSAs) over the period 1969-1992. In 1990 the MSAs in my sample accounted for $80.0 \%$ of the personal income earned and $76.5 \%$ of the total population residing in U.S. counties located on the U.S.Mexico border. ${ }^{6}$ For each U.S. border MSA, I include data on six industries: manufacturing, transport, retail trade, wholesale trade, the FIRE (finance, insurance, real estate) industries, and services. I exclude government activities, agriculture, mining, and construction.

The Mexico National Institute of Statistics, Geography, and Information (INEGI) provides annual data on employment, value added, and imported inputs in export assembly plants located in Mexican border cities for the period 1974-1989. While maquiladoras do not constitute the universe of manufacturers in Mexico that export, they do account for most manufacturing activity in Mexican border cities and represent a large share of total Mexican exports of manufactures. ${ }^{7}$ No other data on regional export activity in Mexico are available. Maquiladoras are highly concentrated in the border region. In $1989,66.7 \%$ of national maquiladora employment was located in the six Mexican border cities in my sample.

\section{B. Variable Definition}

From equations (3) and (4), the dependent variables in the regressions I estimate are log employment and the log average wage for one-digit industries located in U.S. border MSAs. I calculate the average wage as annual payroll per worker, deflated by the U.S. CPI. The

\footnotetext{
6 The excluded U.S. border cities are too small to be classified as MSAs. In 1990 none of the excluded cities, except Douglas, Arizona, had a population greater than 40,000 inhabitants.

7 In 1990 maquiladora exports accounted for $52.2 \%$ of total Mexican exports of manufactures and $42.2 \%$ of total Mexican exports to the United States.
} 
independent variables specified by the model are the alternative wage for workers in a U.S. cityindustry, factors which shift domestic demand for city-industry output, and export production in the Mexican border city that neighbors the U.S. border city.

I measure the alternative wage in a city-industry as the average wage for workers in the industry at the state level, deflated by the U.S. CPI, excluding the MSA on which the observation is taken. The border cities in my sample are located in California or Texas. These states are sufficiently large relative to individual border cities that state labor markets can be treated as independent of innovations in border-city labor markets.

I identify two variables that shift the domestic demand for city-industry output. The first is total personal income in the state in which the MSA is located $\left(I N C_{y j}\right)$, deflated by the U.S. CPI, which, to avoid introducing simultaneity, I measure excluding the MSA on which the observation is taken. State personal income captures local demand for goods and services. The second variable is total employment in the national industry $\left(U S L_{i j}\right)$, which I measure excluding the state in which the MSA is located. National-industry employment captures national-industry labor-demand shocks. I exclude the relevant state in measuring national-industry employment to avoid creating simultaneity between national-industry employment and the alternative wage.

I measure foreign demand for U.S. border city-industry output using economic activity in export assembly plants located in the Mexican border city that neighbors the U.S. MSA (see

\footnotetext{
"In 1990 private, non-farm employment in San Diego, the largest Califomia border city, was $7.7 \%$ of the state level, and private, non-farm employment in El Paso, the largest Texas border city, was $2.7 \%$ of the state level. The more important question is whether the state industry represents the relevant alternative labor market for workers in a city-industry. Data from the United States Census of Population show that there is a substantial amount of labor mobility in California and Texas. Between 1980 and 1990 in-migration from other U.S. counties accounted for over 60 percent of total population growth in the California border cities and over 30 percent of total population growth in all Texas border cities, except Laredo. In all border cities, the majority of in-migration took the form of individuals moving between countries in the same state.
} 
Table 1). For industries in San Diego, then, I measure foreign demand using data on export activity in maquiladoras located in Tijuana. I measure export activity as value added in maquiladoras, converted into dollars and deflated by the U.S. PPI. If the expansion of export manufacturing in Mexico increases the demand for goods and services produced in U.S. border cities, I expect employment in a U.S. border city-industry to be positively correlated with value added in maquiladoras located in the neighboring Mexican border city. As suggested in the introduction, export manufacturing in Mexico may create demand for specific goods and services produced in U.S. border cities. In this case, industries within a border city will respond unevenly to an increase in output by Mexican export assembly plants. I control for this possibility by allowing the coefficient on maquiladora value added to vary across one-digit industries. Table 2 gives definitions and summary statistics for the regression variables.

\section{The Border Economy}

At the level of summary statistics, the data are consistent with the hypothesis that economic activity in the United States is shifting towards cities on the U.S.-Mexico border and that this shift is coincident with expanding U.S.-Mexico trade. Table 3 shows average annual employment growth rates at the one-digit level for U.S. border cities, U.S. border states, and the United States as a whole for the period 1970-1990. Employment growth in U.S. border cities has been rapid in most industries, both in absolute terms and relative to the state and national level. A salient feature of recent border economic development is that it has defied the national trend of a shift out of manufacturing and into services. In all U.S. border urban areas, except Imperial County, average annual employment growth in manufacturing exceeded $2.75 \%$, compared with 
annual growth rates of $1.30 \%$ in California, $1.37 \%$ in Texas, and $-0.004 \%$ in the nation as a whole. While border-city employment growth was also rapid in services, with the exception of San Diego it was generally no more rapid than service employment growth at the state level.

Coinciding with rapid employment growth in U.S. border cities, there has been a dramatic expansion in export manufacturing in Mexican border cities. Mexico first permitted the creation of export assembly plants in $1965 .^{9}$ Prior to trade liberalization in 1985, the maquiladoras constituted a free-trade enclave within the Mexican economy. Export assembly plants were exempt from Mexico's high tariffs and restrictive import-license requirements and unbound by government regulations on foreign investment. The plants could import inputs duty-free, as long as they exported all output, and could be 100 percent foreign owned. Initially, maquiladoras were confined to special enterprise zones located within 20 kilometers of the U.S.-Mexico border. While policy changes in the 1970 s allowed the plants to locate in most regions of the country, the export assembly industry has remained highly concentrated in the border region. In 1990, $85.6 \%$ of export assembly plants were located in Mexican states that border the United States.

Over the last two decades, maquiladoras in Mexican border cities bave expanded rapidly. Table 4 shows annual average growth rates in value added, employment, and imported inputs for export assembly plants in the six Mexican border cities over the period 1974-1989. In all Mexican border cities except Mexicali, average annual employment growth in maquiladoras was greater than $7.0 \%$ and average annual growth in imported inputs by maquiladoras was greater that $13.0 \%$. The vast majority of inputs that maquiladoras import are produced in the United States.

9 Prior to NAFTA, exports by Mexican assembly plants received tariff breaks in the United States under the U.S. offshore assembly provision (items $\mathbf{9 8 0 2 . 0 0 . 6 0}$ and $\mathbf{9 8 0 2 . 0 0 . 8 0}$ of the Harmonized Tariff Schedule). U.S. components that are sent abroad for processing are allowed to reenter the country duty free. 
In 1990 imported inputs accounted for $98.2 \%$ of non-labor input consumption by maquiladoras.

If export manufacturing growth in Mexican border cities contributes to employment growth in U.S. border cities, this pattern should be evident at the level of individual border-city

pairs. The graphs in Figure 1 plot the annual log change in employment in a U.S. border city and the annual log change in maquiladora value added in the neighboring Mexican border city. U.S. border-city employment is for the six one-digit industries in my sample. In three of the bordercity pairs, Brownsville-Matamoros, El Paso-Ciudad Juarez, and Imperial-Mexicali, there is a strong, positive correlation between U.S. border-city employment growth and growth in maquiladora value added. In two other border-city pairs, McAllen-Reynosa and San DiegoTijuana, there is a strong, positive correlation after 1982 . Only one border-city pair, LaredoNuevo Laredo, shows a weak correlation over the whole period.

\section{Empirical Results}

I report OLS and IV estimation results for equations (3) and (4). Observations are pooled over U.S. border city-industries for the period 1975-1989. Regressions are in levels and for time differences of one, three, and five years. Levels regressions include dummy variables for the year and city-industry; time-difference regressions include dummy variables for the year.

\section{A. Employment Regression Results}

Table 5 shows OLS and IV estimation results for U.S. border city-industry employment. Consider first the coefficient estimates on value added in Mexican export assembly plants. In all regressions, except those for a time difference of one year, the coefficient on maquiladora 
value added is positive and statistically significant at a one-percent level. This finding is consistent with the hypothesis that an increase in export manufacturing in Mexican border cities increases the demand for goods and services produced in U.S. border cities. The magnitude of the coefficient estimate on the variable, however, varies widely across specifications. In both the OLS and IV regressions coefficient estimates on maquiladora value added are largest in the levels regression and the regression with a time five-year difference and smallest in the regression with a one-year time difference. This pattern is consistent with the presence of measurement error.

IV corrects for measurement error and endogeneity bias. The instruments I use for maquiladora value added are the other independent variables and lagged values of the suspect variable. Table 5 shows that IV coefficient estimates on maquiladora value added are uniformly larger than OLS estimates. Using a Hausman (1978) specification test, I reject the null hypothesis that maquiladora value added is uncorrelated with the error term at a one-percent level of significance in three of the four regressions. The most reliable coefficient estimates, then, are those from levels and long time-difference IV regressions. Both give similar results.

Results for other independent variables are sensible and relatively stable across specifications. State personal income is positive and statistically significant in all regressions but one, and national-industry employment is positive and statistically significant in all regressions. ${ }^{10}$ This is consistent with the idea that a positive demand shock to city-industry output leads to an increase city-industry employment. The alternative wage is negative in all regressions, though statistically significant in only two. This is consistent with the idea that workers leave a cityindustry in response to higher wage offers elsewhere.

\footnotetext{
10 The threshold level for statistical significance I use is five percent.
} 
The estimation results strongly support the hypothesis that export manufacturing growth in Mexican border cities contributes to employment growth in U.S. border cities. So far, I have constrained the effect of Mexican export production to be uniform across U.S. border industries. I proceed to examine the nature of demand linkages between U.S. and Mexican border cities by allowing the coefficient on maquiladora value added to vary across one-digit industries. Table 6 presents OLS and IV estimation results for the employment equation. Given the results in Table 5, I show results for regressions in levels and a time difference of five years.

The regressions with industry-varying coefficients show a striking pattern: the effect of maquiladora value added on employment in U.S. border cities is positive and statistically significant for all industries, but the effect is uniformly larger for the manufacturing industry. In the IV levels regression the coefficient estimate on maquiladora value added is 0.490 for the manufacturing industry, compared to 0.280 for the next highest industry (transport). A similar pattern exists in the time-difference regressions. As in the previous results, coefficient estimates on maquiladora value added are higher in IV regressions than in OLS regressions.

To formally test the hypothesis that growth in maquiladora value added has a stronger effect on the U.S. border manufacturing industry than on other U.S. border industries, I perform a series of F-tests, which are summarized in Table 6. In all regressions, I reject the null hypothesis that the coefficient on maquiladora value added is constant across all industries at the five-percent level, but I fail to reject the null hypothesis that the coefficient on maquiladora value added in constant across all non-manufacturing industries.

The quantitative impact of export manufacturing in Mexico on U.S. border employment implied by the estimation results is substantial. The results of the OLS and IV levels regressions 
in Table 6 imply that a $10.0 \%$ increase in export production in a Mexican border city leads to a $2.4 \%$ to $4.9 \%$ increase in manufacturing employment in the neighboring U.S. border city. Such an effect is quantitatively significant, especially when considering that growth in maquiladora value added has averaged more than 10 percent per year in five of the six Mexican border cities over the sample period (see Table 4). A $10.0 \%$ increase in Mexican export production leads to an increase in employment by $1.7 \%$ to $2.8 \%$ in the U.S. border transport industry and $1.4 \%$ to 2.4\% in the U.S. border wholesale-trade industry. Even services -- the industry least affected -experiences an employment rise of $1.3 \%$ to $1.6 \%$.

As export manufacturing expands in Mexican border cities, a wide range of activities expand in U.S. border cities. The strongest effect is on the U.S. border manufacturing industry, which may include input production for Mexican export assembly plants. This suggests that U.S.-Mexico trade has stronger effects on U.S. industry location than has been realized. As U.S. manufacturers move their assembly operations from domestic sites to Mexico, they also appear to relocate complementary manufacturing activities to U.S. border cities. The U.S.-Mexico border is not just a site for low-skill product assembly, but is a burgeoning binational regional production center. To the extent that NAFTA reinforces Mexico's specialization in assembly activities, it will also reinforce this pattern of development. That transport and wholesale trade expand with U.S.-Mexico trade is consistent with the hypothesis that integration is converting the border region into a distribution center for the North American market. As NAFTA further expands U.S.-Mexico trade, it should also reinforce this pattern of development. 


\section{B. Wage Regressions}

The wages I observe are averages by city and one-digit industry. In principle, I cannot determine whether a wage rise is due to the fact that wages for the typical worker in a cityindustry bave risen or that the average skill level of the labor force in a city-industry has risen. If, however, labor supply elasticities at the city-industry level are large, as we expect to be the case, then wage changes will primarily reflect changes in the composition of the labor force.

Table 7 shows OLS and IV estimation results for U.S. border city-industry wages. Not surprisingly, the key determinant of city-industry wages are wages in the state industry (outside of the MSA). The alternative wage is positive and highly significant in all regressions. This is consistent with the idea that as the alternative wage for workers in a city-industry rises, workers leave the city-industry, causing local wages to rise in response. The change in the local cityindustry wage in response to a change in the alternative wage is approximately one for one.

In contrast to the employment regressions, the coefficient estimate on maquiladora value added is negative, small in absolute value, and relatively stable across specifications. For OLS, the coefficient estimate ranges from -0.016 in the levels regression to -0.033 in the regression for a time difference of five years; the variable is statistically significant in one regression. For IV, the coefficient estimate varies from -0.039 in the levels regression to -0.071 in the regression for a time difference of three years; the variable is statistically significant in two regressions. The weak, negative correlation between maquiladora value added and U.S. border-city wages may reflect that as a border city-industry grows it attracts workers that are on average younger or less experienced than workers currently employed in the city-industry. " Neither state personal income

"This is consistent with empirical evidence on labor mobility, which shows that younger workers are more mobile than older workers (Borjas, Bronars, and Trejo 1992). 
nor national-industry employment is statistically significant in any regression. In unreported regressions, I allow the coefficient on maquiladora value added to vary across one-digit industries. Given the results in Table 7, it is not surprising that I find that there is little variation across industries in the effects of maquiladora value added on U.S. border city wages.

\section{Sensitivity Analysis}

A possible concern about the sample of U.S. border cities I have chosen is that they represent widely disparate patterns of economic development. San Diego is a city of over two million inhabitants with a modern manufacturing industry; Imperial Country has less than 120,000 inhabitants and relatively primitive manufacturing operations. At the one-digit level, manufacturing employment in San Diego may differ substantially from that in Imperial County. To see if such issues affect the results, I drop the two California cities from the sample and reestimate the employment and wage regressions for the four Texas border cities. The Texas border cities are relatively similar in terms of the manufacturing and other activities they support.

Tables 8 and 9 report OLS and IV employment and wage-equation estimation results for the Texas border MSAs. The reported regressions are in levels and for a time difference of five years. I allow the coefficient on maquiladora value added to vary across one-digit industries in the employment regressions. The results are similar to those in Tables 6 and 7 . In the employment regressions maquiladora value added is again positive and statistically significant for most industries, with substantially higher coefficient estimates for the manufacturing industry. In the wage regressions maquiladora value added is negative, small in absolute value, and statistically significant in all regressions. 
While I do find that Mexican export manufacturing is positively correlated with manufacturing employment in U.S. border cities, I do not show that employment is contracting in any specific U.S. location. It is perhaps inappropriate to conclude that manufacturing growth in U.S. border cities is the result of industry relocation, even though net U.S. job growth in manufacturing is near zero over the sample period. The problem I face in identifying such an effect is that there is no clear logic for matching interior U.S. cities with specific Mexican border cities. One solution is to match Mexican border cities with the nearest non-border interior U.S. city. If I find no correlation between Mexican export manufacturing and employment or wages in these U.S. cities, I am lead to believe that the binational production centers I have identified are confined to border-city pairs. In unreported results, I replaced San Diego with Los Angeles, El Paso with Las Cruces, New Mexico, and Laredo, McAllen, and Brownsville with San Antonio, Texas, and reestimated equations (3) and (4). In no case did I find a statistically significant relationship between maquiladora value added and employment in the interior U.S. cities.

\section{Concluding Remarks}

In this paper, I examine whether the growth of export manufacturing in Mexican border cities affects the demand for goods and services produced in U.S. border cities. I find that a $10.0 \%$ increase in Mexican export manufacturing leads to a $2.4 \%$ to $4.9 \%$ percent increase in U.S. border-city manufacturing employment. A positive, but smaller, effect exists for nonmanufacturing U.S. border industries. Average wages in U.S. border cities show a small, negative correlation with export manufacturing in Mexico.

The results suggest that as NAFTA completes the process of U.S.-Mexico economic 
integration the border region will become an increasingly important site for U.S. manufacturing. Integration between countries is contributing to the formation of vertical production networks that span the U.S.-Mexico border. To the extent that the manufacturing activities that are expanding in U.S. border cities represent activities that previously took place in interior U.S. sites, NAFTA is likely to have a much larger impact on industry location than has been recognized. My finding that international trade matters for industry location within countries is consistent with recent work in trade theory. The approach I take in this paper could be easily replicated for European cities. In Europe the process of economic integration is more advanced and we would expect binational regional production networks to be more developed.

The data for this study cover the pre-NAFTA period, during which time trade liberalization and other reforms in Mexico initiated the process of U.S.-Mexico integration. A question remains about whether the pre-NAFTA pattern of trade is an accurate indication of the post-NAFTA pattern of trade. In general the pre-NAFTA pattern of specialization between the United States and Mexico accords with what economic intuition suggests is each country's comparative advantage. Mexico specialized in unskilled-labor-intensive activities, such as product assembly, and the United States specialized in skilled-labor-intensive activities, such as product design and the production of parts and components. Given that in most industries pre-NAFTA trade barriers in the United States and Mexico were low, there is little reason to believe that post NAFTA the pattern of specialization will be fundamentally different. In this case, the process of complementary manufacturing development we observe in U.S. and Mexican border cities during the 1980 s is a good predictor for the effects of further integration. 


\section{References}

Baldwin, R. and A. Venables. 1995. "Regional Integration." Mimeo.

Borjas, G., S. Bronars, and S. Trejo. 1992. "Self-Selection and Internal Migration in the United States." Joumal of Urban Economics 26: .

Brown, D.K., A.V. Deardorff, and R.M. Stern. 1992. "North American Integration." Economic Joumal 102: 1507-1519.

Francois, J.F. and C.R. Shiells. 1994. Modelling Trade Policy: Applied General Equilibrium A ssessments of North American Free Trade. Cambridge: Cambridge University Press.

Griliches, Z. 1986. "Economic Data Issues." In Z. Griliches and M.D. Intriligator, eds., Handbook of Econometrics, Volume III, Amsterdam: North-Holland.

Griliches, Z. and J.A. Hausman. 1986. "Errors in Variables in Panel Data." Journal of Econometrics 31: 93-118.

Grossman, G.M. 1987. "The Employment and Wage Effects of Import Competition." Joumal of International Economic Integration II: 1-23.

Hamermesh, D.S. 1993. Labor Demand. Princeton: Princeton University Press.

Hausman, J.A. 1978. "Specification Texts in Econometrics." Econometrica 46: 1251-71.

Henderson, J.V. 1982. "Systems of Cities in Closed and Open Economies." Regional Science and Urban Economics 12: 325-350.

Krugman, P. and R. Livas. 1992. "Trade Policy and the Third World Metropolis." NBER Working Paper No. 4238.

Krugman, P. and A.J. Venables. 1990. "Integration and the Competitiveness of Peripheral Industry." In C. Bliss and J. Braga de Macedo, eds., Unity with Diversity in the European Community, Cambridge: Cambridge University Press.

Krugman, P. and A.J. Venables. 1996. "Integration, Specialization and Adjustment." European Economic Review, forthcoming.

Lustig, N. 1992. Mexico: The Remaking of an Economy. Washington: The Brookings Institution.

Lustig, N., B.P. Bosworth, and R.Z. Lawrence. 1992. Assessing the Impact of North American Free Trade. Washington: The Brookings Institution. 
Rauch, J.E. 1989. "Increasing Returns and the Pattern of Trade." Joumal of Intermational Economics 26: 359-369.

Rauch, J.E. 1993. "Comparative Advantage, Geographic Advantage, and the Volume of Trade." Economic Joumal 101: 1230-1244.

Revenga, A.L. 1992. "Exporting Jobs: The Impact of Import Competition on Employment and Wages in U.S. Manufacturing." Quarterly Joumal of Economics 107: 255-284. 
Table 1: U.S.-Mexico Border-City Pairs

\begin{tabular}{lcclcr}
$\begin{array}{l}\text { United States } \\
\text { Border City }\end{array}$ & \multicolumn{2}{c}{ Population ('000s) } & \multicolumn{2}{c}{ Mexico } & \multicolumn{2}{c}{$\begin{array}{l}\text { Population ('000s) } \\
\text { San Diego, CA }\end{array}$} & 1980 & 1990 & Border City & 1980 & 1990 \\
\hline Imperial, CA & 92.9 & 111.1 & Mexicali & 561.3 & 747.4 \\
El Paso, TX & 484.4 & 596.4 & Ciudad Juarez & 567.4 & 798.5 \\
Laredo, TX & 100.5 & 134.6 & Nuevo Laredo & 203.3 & 219.5 \\
McAllen, TX & 287.0 & 387.0 & Reynosa & 211.4 & 282.7 \\
Brownsville, TX & 212.2 & 261.9 & Matamoros & 238.8 & 303.3 \\
\hline
\end{tabular}

Sources: U.S. BEA, Regional Economic Information System; Mexico Censo de Poblacion, various years.

U.S. border cities are Metropolitan Statistical Areas (MSAs), as defined by the BEA. MSAs are defined on a county-wide basis. MSA names apply to the largest metropolitan area in the county or group of counties that compose the MSA. The two major cities in Imperial County, California, Calexico and El Centro, are too small to be classified as MSAs. I use data on Imperial County to measure economic activity in the Calexico-El Centro urban area. 
Table 2: Variable Definitions and Summary Statistics

\begin{tabular}{|c|c|c|c|c|}
\hline Variable & $\begin{array}{l}\text { Definition } \\
(\mathrm{i}=\mathrm{MSA}, \mathrm{j}=\text { industry, } \mathrm{t}=\text { year) }\end{array}$ & Mean & $\begin{array}{l}\text { Standard } \\
\text { Deviation }\end{array}$ & $\begin{array}{l}\text { No. of } \\
\text { Obs. }\end{array}$ \\
\hline$\Delta \ln \mathrm{L}_{\mathrm{ijt}}$ & $\begin{array}{l}\text { City-Industry Employment: } \\
\Delta \log \text { (average annual one-digit industry } \\
\text { employment in MSA) }\end{array}$ & 0.033 & 0.063 & 504 \\
\hline$\Delta \ln W_{i j t}$ & $\begin{array}{l}\text { City-Industry Wage: } \\
\Delta \log \text { ([annual one-digit industry payroll } \\
\text { in MSA/average annual one-digit indus- } \\
\text { try employment in MSA]/U.S. CPI) }\end{array}$ & -0.005 & 0.061 & 504 \\
\hline$\Delta \ln W^{A}{ }_{i j t}$ & $\begin{array}{l}\text { Alternative Wage: } \\
\Delta \log \text { ([annual one-digit industry payroll } \\
\text { in state outside MSA/average annual } \\
\text { one-digit industry employment in state } \\
\text { outside MSA]/U.S. CPI) }\end{array}$ & 0.002 & 0.041 & 504 \\
\hline$\Delta \ln I N C_{i j t}$ & $\begin{array}{l}\text { State Personal Income: } \\
\Delta \log \text { (total personal income in state } \\
\text { outside of MSA/U.S. CPI) }\end{array}$ & 0.038 & 0.024 & 504 \\
\hline$\Delta \ln U S L_{i j t}$ & $\begin{array}{l}\text { National-Industry Employment: } \\
\Delta \text { log (average annual one-digit industry } \\
\text { employment in U.S. outside of state } \\
\text { in which MSA is located) }\end{array}$ & 0.024 & 0.023 & 504 \\
\hline$\Delta \ln E X P_{i j t}$ & $\begin{array}{l}\text { Maquiladora Value Added: } \\
\Delta \log \text { ([value added in maquiladoras } \\
\text { located in Mexican border city } \\
\text { neighboring U.S. MSA*U.S.-Mexico } \\
\text { exchange rate]/U.S. PPI) }\end{array}$ & 0.128 & 0.239 & 84 \\
\hline
\end{tabular}

Observations for all variables are for the period 1975-1989. The reported average log changes are for periods of one year. 
Table 3: Average Annual Employment Growth in Border MSAs and States by One-Digit Industry, 1970-90 (standard errors in parentheses)

\begin{tabular}{|c|c|c|c|c|c|c|}
\hline Region & Manufact. & Transport & $\begin{array}{l}\text { Wholesale } \\
\text { Trade }\end{array}$ & $\begin{array}{l}\text { Retail } \\
\text { Trade }\end{array}$ & FIRE & Services \\
\hline $\begin{array}{l}\text { United } \\
\text { States }\end{array}$ & $\begin{array}{l}-0.004 \\
(0.039)\end{array}$ & $\begin{array}{c}0.015 \\
(0.020)\end{array}$ & $\begin{array}{c}0.022 \\
(0.019)\end{array}$ & $\begin{array}{c}0.025 \\
(0.016)\end{array}$ & $\begin{array}{c}0.027 \\
(0.019)\end{array}$ & $\begin{array}{c}0.039 \\
(0.012)\end{array}$ \\
\hline Califomia & $\begin{array}{c}0.013 \\
(0.043)\end{array}$ & $\begin{array}{c}0.019 \\
(0.023)\end{array}$ & $\begin{array}{c}0.035 \\
(0.022)\end{array}$ & $\begin{array}{c}0.033 \\
(0.017)\end{array}$ & $\begin{array}{c}0.035 \\
(0.023)\end{array}$ & $\begin{array}{c}0.051 \\
(0.017)\end{array}$ \\
\hline San Diego & $\begin{array}{c}0.034 \\
(0.059)\end{array}$ & $\begin{array}{c}0.038 \\
(0.022)\end{array}$ & $\begin{array}{c}0.058 \\
(0.045)\end{array}$ & $\begin{array}{c}0.049 \\
(0.026)\end{array}$ & $\begin{array}{c}0.052 \\
(0.041)\end{array}$ & $\begin{array}{c}0.066 \\
(0.019)\end{array}$ \\
\hline Imperial & $\begin{array}{c}0.000 \\
(0.120)\end{array}$ & $\begin{array}{c}0.015 \\
(0.057)\end{array}$ & $\begin{array}{c}0.023 \\
(0.103)\end{array}$ & $\begin{array}{c}0.018 \\
(0.047)\end{array}$ & $\begin{array}{c}0.028 \\
(0.060)\end{array}$ & $\begin{array}{c}0.037 \\
(0.033)\end{array}$ \\
\hline Texas & $\begin{array}{c}0.014 \\
(0.045)\end{array}$ & $\begin{array}{c}0.028 \\
(0.028)\end{array}$ & $\begin{array}{c}0.026 \\
(0.029)\end{array}$ & $\begin{array}{c}0.033 \\
(0.020)\end{array}$ & $\begin{array}{c}0.040 \\
(0.036)\end{array}$ & $\begin{array}{c}0.048 \\
(0.018)\end{array}$ \\
\hline Brownsville & $\begin{array}{c}0.044 \\
(0.099)\end{array}$ & $\begin{array}{c}0.021 \\
(0.091)\end{array}$ & $\begin{array}{c}0.014 \\
(0.078)\end{array}$ & $\begin{array}{c}0.036 \\
(0.041)\end{array}$ & $\begin{array}{c}0.042 \\
(0.065)\end{array}$ & $\begin{array}{c}0.052 \\
(0.031)\end{array}$ \\
\hline El Paso & $\begin{array}{c}0.030 \\
(0.059)\end{array}$ & $\begin{array}{c}0.016 \\
(0.035)\end{array}$ & $\begin{array}{c}0.032 \\
(0.040)\end{array}$ & $\begin{array}{c}0.036 \\
(0.023)\end{array}$ & $\begin{array}{c}0.031 \\
(0.049)\end{array}$ & $\begin{array}{c}0.049 \\
(0.018)\end{array}$ \\
\hline Laredo & $\begin{array}{c}0.028 \\
(0.113)\end{array}$ & $\begin{array}{c}0.058 \\
(0.088)\end{array}$ & $\begin{array}{c}0.040 \\
(0.108)\end{array}$ & $\begin{array}{c}0.037 \\
(0.083)\end{array}$ & $\begin{array}{c}0.050 \\
(0.041)\end{array}$ & $\begin{array}{c}0.042 \\
(0.059)\end{array}$ \\
\hline McAllen & $\begin{array}{c}0.069 \\
(0.072)\end{array}$ & $\begin{array}{c}0.036 \\
(0.046)\end{array}$ & $\begin{array}{c}0.036 \\
(0.113)\end{array}$ & $\begin{array}{c}0.050 \\
(0.047)\end{array}$ & $\begin{array}{c}0.053 \\
(0.041)\end{array}$ & $\begin{array}{c}0.058 \\
(0.034)\end{array}$ \\
\hline
\end{tabular}

The FIRE industries are finance, insurance, and real estate. Source: U.S. BEA, Regional Economic Information system. 
Table 4: Annual Average Growth in Export Manufacturing in Mexican Border Cities, 1975-89 (standard errors in parentheses)

\begin{tabular}{|c|c|c|c|c|}
\hline Mexican & Neighboring & Average Annt & th in Mexican & Assembly Plants: \\
\hline City & U.S. MSA & Employment & Value Added & Imported Inputs \\
\hline Tijuana & San Diego & $\begin{array}{c}0.120 \\
(0.129)\end{array}$ & $\begin{array}{c}0.112 \\
(0.212)\end{array}$ & $\begin{array}{c}0.165 \\
(0.203)\end{array}$ \\
\hline Mexicali & Imperial & $\begin{array}{c}0.067 \\
(0.157)\end{array}$ & $\begin{array}{c}0.073 \\
(0.187)\end{array}$ & $\begin{array}{c}0.052 \\
(0.164)\end{array}$ \\
\hline Matamoros & Brownsville & $\begin{array}{c}0.093 \\
(0.085)\end{array}$ & $\begin{array}{c}0.102 \\
(0.183)\end{array}$ & $\begin{array}{c}0.158 \\
(0.257)\end{array}$ \\
\hline Cd. Juarez & El Paso & $\begin{array}{c}0.127 \\
(0.075)\end{array}$ & $\begin{array}{c}0.111 \\
(0.140)\end{array}$ & $\begin{array}{c}0.132 \\
(0.162)\end{array}$ \\
\hline N. Laredo & Laredo & $\begin{array}{c}0.072 \\
(0.335)\end{array}$ & $\begin{array}{c}0.158 \\
(0.339)\end{array}$ & $\begin{array}{c}0.234 \\
(0.346)\end{array}$ \\
\hline Reynosa & McAllen & $\begin{array}{c}0.210 \\
(0.221)\end{array}$ & $\begin{array}{c}0.209 \\
(0.330)\end{array}$ & $\begin{array}{c}0.255 \\
(0.404)\end{array}$ \\
\hline
\end{tabular}

Value added and imported inputs are converted into dollars and deflated by the U.S. PPI. Annual growth rates are annual average log changes. Source: Mexico National Institute for Statistics, Geography, and Information (INEGI). 
Table 5: U.S. Border City-Industry Employment Estimation Results (standard errors in parentheses)

\begin{tabular}{|c|c|c|c|c|c|c|c|c|}
\hline Estimation Method & OLS & OLS & OLS & OLS & IV & IV & IV & IV \\
\hline Time Difference & Levels & 1 year & 3 years & 5 years & Levels & 1 year & 3 years & 5 years \\
\hline $\operatorname{lnSWG}$ & $\begin{array}{l}-0.0654 \\
(0.0989)\end{array}$ & $\begin{array}{l}-0.1188 \\
(0.0706)\end{array}$ & $\begin{array}{l}-0.1900^{\circ} \\
(0.0864)\end{array}$ & $\begin{array}{l}-0.0989 \\
(0.1197)\end{array}$ & $\begin{array}{l}-0.0627 \\
(0.1028)\end{array}$ & $\begin{array}{l}-0.1119 \\
(0.0752)\end{array}$ & $\begin{array}{l}-0.2058^{*} \\
(0.0897)\end{array}$ & $\begin{array}{l}-0.0945 \\
(0.1238)\end{array}$ \\
\hline $\ln \mathbb{N C}$ & $\begin{array}{l}0.5562^{* *} \\
(0.1787)\end{array}$ & $\begin{array}{l}0.8746^{\circ *} \\
(0.1890)\end{array}$ & $\begin{array}{l}0.8105^{* *} \\
(0.1669)\end{array}$ & $\begin{array}{l}0.5683^{\circ} \\
(0.1827)\end{array}$ & $\begin{array}{l}0.4505^{*} \\
(0.1874)\end{array}$ & $\begin{array}{l}0.9492^{* *} \\
(0.3200)\end{array}$ & $\begin{array}{l}0.6416^{\circ *} \\
(0.1820)\end{array}$ & $\begin{array}{l}0.3773 \\
(0.1974)\end{array}$ \\
\hline InUSL & $\begin{array}{l}0.9246 * \\
(0.0763)\end{array}$ & $\begin{array}{l}0.9260^{\circ *} \\
(0.1428)\end{array}$ & $\begin{array}{l}0.9069^{* *} \\
(0.1191)\end{array}$ & $\begin{array}{l}0.9751^{\circ} \\
(0.1052)\end{array}$ & $\begin{array}{l}0.9225^{\circ} \\
(0.0794)\end{array}$ & $\begin{array}{l}0.9279^{* *} \\
(0.1443)\end{array}$ & $\begin{array}{l}0.9031^{* *} \\
(0.1234)\end{array}$ & $\begin{array}{l}0.9735^{\circ *} \\
(0.1087)\end{array}$ \\
\hline $\ln$ EXP & $\begin{array}{l}0.1532^{* *} \\
(0.0196)\end{array}$ & $\begin{array}{l}0.0364 \\
(0.0193)\end{array}$ & $\begin{array}{l}0.0905^{\circ} \\
(0.0206)\end{array}$ & $\begin{array}{l}0.1581^{* *} \\
(0.0253)\end{array}$ & $\begin{array}{l}0.2667^{\circ *} \\
(0.0334)\end{array}$ & $\begin{array}{l}-0.0160 \\
(0.1814)\end{array}$ & $\begin{array}{l}0.1948^{\circ *} \\
(0.0409)\end{array}$ & $\begin{array}{l}0.2684^{\circ \bullet} \\
(0.0424)\end{array}$ \\
\hline $\begin{array}{l}\text { Hausman Specification } \\
\text { Test statistic }\end{array}$ & & & & & $-4.560^{\circ *}$ & 0.293 & $-3.143^{\circ *}$ & $-3.491^{* \bullet}$ \\
\hline Adjusted $\mathbf{R}^{2}$ & 0.995 & 0.317 & 0.335 & 0.393 & 0.995 & 0.304 & 0.286 & 0.352 \\
\hline $\mathbf{N}$ & 468 & 396 & 360 & 288 & 468 & 396 & 360 & 288 \\
\hline
\end{tabular}

* $\left({ }^{* *}\right)$ Indicates statistical significance at the five (one) percent level. Levels regressions include dummy variables for the city-industry and the year, time-difference regressions include dummy variables for the year. The instruments in the IV regressions are the exogenous independent variables ( $\operatorname{lnSWG}, \ln I N C, \ln U S L)$ and the second lag of $\operatorname{lnEXP}$ (for time-difference regressions, instruments are in time-difference fom). 
Table 6: Employment Regressions with Industry-Varying Coefficients (standard errors in parentheses)

\begin{tabular}{|c|c|c|c|c|}
\hline Estimation Method & OLS & OLS & IV & IV \\
\hline Time Difference & Levels & 5 years & Levels & 5 years \\
\hline $\ln S W G$ & $\begin{array}{l}-0.1901 \\
(0.1064)\end{array}$ & $\begin{array}{c}-0.1843 \\
(0.1263)\end{array}$ & $\begin{array}{l}-0.2325 \\
(0.1203)\end{array}$ & $\begin{array}{c}-0.2118 \\
(0.1392)\end{array}$ \\
\hline $\ln [N C$ & $\begin{array}{l}0.6486^{\circ} \\
(0.1778)\end{array}$ & $\begin{array}{l}0.6358^{\circ *} \\
(0.1819)\end{array}$ & $\begin{array}{l}0.6072^{*} \\
(0.1946)\end{array}$ & $\begin{array}{c}0.4847^{\circ} \\
(0.2021)\end{array}$ \\
\hline $\ln U S L$ & $\begin{array}{l}1.2341^{*} \\
(0.1325)\end{array}$ & $\begin{array}{l}1.3169^{*} \\
(0.1557)\end{array}$ & $\begin{array}{l}1.7822^{*} \\
(0.2835)\end{array}$ & $\begin{array}{l}1.6083^{\circ *} \\
(0.2730)\end{array}$ \\
\hline $\operatorname{lnEXP*MFG~}$ & $\begin{array}{l}0.2426^{\circ} \\
(0.0312)\end{array}$ & $\begin{array}{l}0.2619^{*} \\
(0.0402)\end{array}$ & $\begin{array}{l}0.4899^{\circ} \\
(0.0662)\end{array}$ & $\begin{array}{l}0.4709 * \\
(0.0756)\end{array}$ \\
\hline $\ln E X P * T R N$ & $\begin{array}{l}0.1681^{* \bullet} \\
(0.0256)\end{array}$ & $\begin{array}{l}0.1832^{*} \\
(0.0349)\end{array}$ & $\begin{array}{l}0.2805^{* *} \\
(0.0420)\end{array}$ & $\begin{array}{l}0.2771^{* *} \\
(0.0549)\end{array}$ \\
\hline $\operatorname{lnEXP*WTR}$ & $\begin{array}{l}0.1433^{*} \\
(0.0253)\end{array}$ & $\begin{array}{l}0.1549^{*} \\
(0.0346)\end{array}$ & $\begin{array}{l}0.2437^{*} \\
(0.0405)\end{array}$ & $\begin{array}{l}0.2411^{\circ} \\
(0.0534)\end{array}$ \\
\hline $\operatorname{lnEXP*RTR}$ & $\begin{array}{l}0.1022^{\circ} \\
(0.0263)\end{array}$ & $\begin{array}{l}0.1075^{*} \\
(0.0354)\end{array}$ & $\begin{array}{l}0.1838^{*} \\
(0.0435)\end{array}$ & $\begin{array}{l}0.1872^{*} \\
(0.0561)\end{array}$ \\
\hline $\operatorname{lnEXP*FIRE}$ & $\begin{array}{l}0.1291^{* *} \\
(0.0255)\end{array}$ & $\begin{array}{l}0.1200^{* *} \\
(0.0350)\end{array}$ & $\begin{array}{l}0.2102^{*} \\
(0.0415)\end{array}$ & $\begin{array}{l}0.2245^{*} \\
(0.0550)\end{array}$ \\
\hline $\operatorname{lnEXP*SERV}$ & $\begin{array}{l}0.1304^{\circ} \\
(0.0310)\end{array}$ & $\begin{array}{l}0.1184^{*} \\
(0.0399)\end{array}$ & $\begin{array}{l}0.1562^{\circ} \\
(0.645)\end{array}$ & $\begin{array}{l}0.1845^{\circ} \\
(0.0740)\end{array}$ \\
\hline $\begin{array}{l}\text { F-statistic on } \mathrm{H}_{0}: \ln E X P \\
\text { coefficients equal }\end{array}$ & $\begin{array}{c}3.64^{*} \\
F[5,411]\end{array}$ & $\begin{array}{c}2.66^{\circ} \\
F[5,271]\end{array}$ & $\begin{array}{c}4.88^{\circ \bullet} \\
F[5,411]\end{array}$ & $\begin{array}{c}2.84^{\circ} \\
\mathrm{F}[5,271]\end{array}$ \\
\hline $\begin{array}{l}\text { F-statistic on } \mathrm{H}_{0}: \ln E X P \\
\text { coefficients equal } \\
\text { (excluding manuf.) }\end{array}$ & $\begin{array}{c}1.50 \\
F[4,411]\end{array}$ & $\begin{array}{c}1.17 \\
F[4,271]\end{array}$ & $\begin{array}{c}1.34 \\
F[4,411]\end{array}$ & $\begin{array}{c}0.64 \\
F[4,271]\end{array}$ \\
\hline Adjusted $\mathrm{R}^{2}$ & 0.996 & 0.411 & 0.995 & 0.346 \\
\hline $\mathbf{N}$ & 468 & 288 & 468 & 288 \\
\hline
\end{tabular}

* (*) Indicates statistical significance at the five (one) percent level. Industry dummy variables: MFG $=$ manufacturing, $T R N=$ transport, $W T R=$ wholesale trade, $R T R=$ retail trade, FIRE = finance/insurance/ real estate, SERV = services. Intercept dummy variables and instruments are analogous to Table 5. 
Table 7: U.S. Border City-Industry Wage Estimation Results

(standard errors in parentheses)

\begin{tabular}{|c|c|c|c|c|c|c|c|c|}
\hline Estimation Method & OLS & OLS & OLS & OLS & IV & IV & IV & IV \\
\hline Time Difference & Levels & 1 year & 3 years & 5 years & Levels & 1 year & 3 years & 5 years \\
\hline $\operatorname{lnSWG}$ & $\begin{array}{l}0.9561^{* \bullet} \\
(0.0625)\end{array}$ & $\begin{array}{l}1.1297^{* *} \\
(0.0556)\end{array}$ & $\begin{array}{l}1.0617^{* *} \\
(0.0577)\end{array}$ & $\begin{array}{l}1.0346 " \\
(0.0751)\end{array}$ & $\begin{array}{l}0.9557^{\circ *} \\
(0.0627)\end{array}$ & $\begin{array}{l}1.1027^{\circ *} \\
(0.0712)\end{array}$ & $\begin{array}{l}1.0689^{\circ *} \\
(0.0588)\end{array}$ & $\begin{array}{l}1.0337^{\circ *} \\
(0.0755)\end{array}$ \\
\hline $\ln [N C$ & $\begin{array}{l}-0.1188 \\
(0.1129)\end{array}$ & $\begin{array}{l}-0.2358 \\
(0.1488)\end{array}$ & $\begin{array}{l}-0.2109 \\
(0.1114)\end{array}$ & $\begin{array}{l}-0.1591 \\
(0.1146)\end{array}$ & $\begin{array}{l}-0.0970 \\
(0.1144)\end{array}$ & $\begin{array}{l}-0.5263 \\
(0.3029)\end{array}$ & $\begin{array}{l}-0.1336 \\
(0.1192)\end{array}$ & $\begin{array}{c}-0.1169 \\
(0.1203)\end{array}$ \\
\hline $\operatorname{lnUSL}$ & $\begin{array}{l}0.0883 \\
(0.0482)\end{array}$ & $\begin{array}{l}0.0271 \\
(0.1124)\end{array}$ & $\begin{array}{c}0.0676 \\
(0.0795)\end{array}$ & $\begin{array}{l}0.0438 \\
(0.0660)\end{array}$ & $\begin{array}{l}0.0887 \\
(0.0484)\end{array}$ & $\begin{array}{c}0.0194 \\
(0.1366)\end{array}$ & $\begin{array}{l}-0.0693 \\
(0.0809)\end{array}$ & $\begin{array}{l}0.0442 \\
(0.0663)\end{array}$ \\
\hline $\operatorname{lnEXP}$ & $\begin{array}{l}-0.0157 \\
(0.0124)\end{array}$ & $\begin{array}{l}-0.0171 \\
(0.0152)\end{array}$ & $\begin{array}{l}-0.0237 \\
(0.0137)\end{array}$ & $\begin{array}{l}-0.0333^{\circ} \\
(0.0159)\end{array}$ & $\begin{array}{l}-0.0391 \\
(0.0204)\end{array}$ & $\begin{array}{l}0.1869 \\
(0.1717)\end{array}$ & $\begin{array}{l}-0.0714^{\circ *} \\
(0.0268)\end{array}$ & $\begin{array}{l}-0.0577^{*} \\
(0.0258)\end{array}$ \\
\hline $\begin{array}{l}\text { Hausman Specification } \\
\text { Test statistic }\end{array}$ & & & & & 1.450 & -1.452 & $2.139^{\circ}$ & 1.207 \\
\hline Adjusted $\mathbf{R}^{2}$ & 0.969 & 0.559 & 0.549 & 0.470 & 0.969 & 0.350 & 0.533 & 0.465 \\
\hline $\mathbf{N}$ & 468 & 396 & 360 & 288 & 468 & 396 & 360 & 288 \\
\hline
\end{tabular}

${ }^{*}\left({ }^{*}\right)$ Indicates statistical significance at the five (one) percent level. Levels regressions include dummy variables for the city-industry and the year, time-difference regressions include dummy variables for the year. The instruments in the IV regressions are the exogenous independent variables ( $\operatorname{lnSWG}, \ln [N C, \ln U S L$ ) and the second lag of $\operatorname{lnEXP}$ (for time-difference regressions, instruments are in time-difference fom). 
Table 8: Employment Regressions for Texas Border MSAs (standard errors in parentheses)

\begin{tabular}{|c|c|c|c|c|}
\hline Estimation Method & OLS & OLS & IV & IV \\
\hline Time Difference & Levels & 5 years & Levels & 5 years \\
\hline InSWG & $\begin{array}{l}-0.0697 \\
(0.1142)\end{array}$ & $\begin{array}{l}-0.1142 \\
(0.1361)\end{array}$ & $\begin{array}{l}-0.1175 \\
(0.1477)\end{array}$ & $\begin{array}{l}-0.1625 \\
(0.1595)\end{array}$ \\
\hline $\ln \Pi N C$ & $\begin{array}{l}-62.5300^{\circ *} \\
(15.0384)\end{array}$ & $\begin{array}{l}-72.4697^{* *} \\
(19.1015)\end{array}$ & $\begin{array}{l}-1.5165^{\circ} \\
(0.4401)\end{array}$ & $\begin{array}{l}-80.1818 * \\
(20.8576)\end{array}$ \\
\hline InUSL & $\begin{array}{l}1.0900^{\circ} \\
(0.1427)\end{array}$ & $\begin{array}{l}1.1677^{\circ} \\
(0.1744)\end{array}$ & $\begin{array}{l}1.8591^{\star *} \\
(0.3722)\end{array}$ & $\begin{array}{l}1.5760^{*} \\
(0.3677)\end{array}$ \\
\hline $\ln E X P * M F G$ & $\begin{array}{l}0.1788^{\circ} \\
(0.0307)\end{array}$ & $\begin{array}{l}0.1947^{\circ} \\
(0.0412)\end{array}$ & $\begin{array}{l}0.4674^{\circ *} \\
(0.0794)\end{array}$ & $\begin{array}{l}0.3939^{*} \\
(0.0900)\end{array}$ \\
\hline $\operatorname{lnEXP*TRN}$ & $\begin{array}{l}0.1309^{* *} \\
(0.0251)\end{array}$ & $\begin{array}{l}0.1650^{\circ} \\
(0.0352)\end{array}$ & $\begin{array}{l}0.2400^{*} \\
(0.0477)\end{array}$ & $\begin{array}{l}0.2052^{*} \\
(0.0568)\end{array}$ \\
\hline $\operatorname{lnEXP*WTR}$ & $\begin{array}{l}0.0612^{* \bullet} \\
(0.0246)\end{array}$ & $\begin{array}{c}0.0802^{\circ} \\
(0.0346)\end{array}$ & $\begin{array}{l}0.1540^{\circ *} \\
(0.0451)\end{array}$ & $\begin{array}{c}0.1109^{\circ} \\
(0.0537)\end{array}$ \\
\hline $\operatorname{lnEXP*RTR}$ & $\begin{array}{l}0.0742^{* \bullet} \\
(0.0257)\end{array}$ & $\begin{array}{c}0.0877^{\circ} \\
(0.0356)\end{array}$ & $\begin{array}{l}0.1484^{* *} \\
(0.0486)\end{array}$ & $\begin{array}{c}0.1140^{\circ} \\
(0.0574)\end{array}$ \\
\hline $\operatorname{lnEXP} *$ FIRE & $\begin{array}{l}0.1188 \\
(0.0251)\end{array}$ & $\begin{array}{l}0.1205^{\circ *} \\
(0.0358)\end{array}$ & $\begin{array}{l}0.1886^{\circ} \\
(0.0466)\end{array}$ & $\begin{array}{l}0.1697^{* *} \\
(0.0563)\end{array}$ \\
\hline $\operatorname{lnEXP*SERV}$ & $\begin{array}{l}0.1068^{* \bullet} \\
(0.0306)\end{array}$ & $\begin{array}{c}0.1052^{\circ} \\
(0.0407)\end{array}$ & $\begin{array}{c}0.1069 \\
(0.0770)\end{array}$ & $\begin{array}{c}0.1203 \\
(0.0865)\end{array}$ \\
\hline $\begin{array}{l}\text { F-statistic on } \mathrm{H}_{0}: \ln \mathrm{EXP} \\
\text { coefficients equal }\end{array}$ & $\begin{array}{c}4.02^{* *} \\
F[5,267]\end{array}$ & $\begin{array}{c}1.90 \\
F[5,175]\end{array}$ & $\begin{array}{c}5.68^{\circ} \\
F[5,267]\end{array}$ & $\begin{array}{c}3.07^{\circ} \\
F[5,175]\end{array}$ \\
\hline $\begin{array}{l}\text { F-statistic on } \mathrm{H}_{0} \text { : } \ln \mathrm{EXP} \\
\text { coefficients equal } \\
\text { (excluding manuf.) }\end{array}$ & $\begin{array}{c}2.71^{\star} \\
F[4,267]\end{array}$ & $\begin{array}{c}1.47 \\
F[4,175]\end{array}$ & $\begin{array}{c}1.57 \\
F[4,267]\end{array}$ & $\begin{array}{c}1.00 \\
F[4,175]\end{array}$ \\
\hline Adjusted $\mathrm{R}^{2}$ & 0.9926 & 0.4608 & 0.9896 & 0.3819 \\
\hline No. of Obs. & 312 & 192 & 312 & 192 \\
\hline
\end{tabular}

* (*) Indicates statistical significance at the five (one) percent level. Industry dummy variables: $M F G$ $=$ manufacturing, TRN $=$ transport, WTR $=$ wholesale trade, $R T R=$ retail trade, FIRE $=$ finance/insurance/ real estate, SERV = services. Intercept dummy variables and instruments are analogous to Table 7. 
Table 9: Wage Regressions for Texas Border MSAs

(standard errors in parentheses)

\begin{tabular}{|c|c|c|c|c|}
\hline Estimation Method & OLS & OLS & IV & IV \\
\hline Time Difference & Levels & 5 years & Levels & 5 years \\
\hline $\operatorname{lnSWG}$ & $\begin{array}{l}1.0264^{\circ *} \\
(0.0614)\end{array}$ & $\begin{array}{l}1.0742^{\circ} \\
(0.0769)\end{array}$ & $\begin{array}{l}1.0267^{\circ *} \\
(0.0621)\end{array}$ & $\begin{array}{l}1.0747^{* *} \\
(0.0779)\end{array}$ \\
\hline $\ln I N C$ & $\begin{array}{c}-7.3864 \\
(9.3858)\end{array}$ & $\begin{array}{l}-11.2620 \\
(12.2965)\end{array}$ & $\begin{array}{c}-0.0984 \\
(0.0593)\end{array}$ & $\begin{array}{c}-6.7840 \\
(12.7157)\end{array}$ \\
\hline $\ln U S L$ & $\begin{array}{c}0.0706 \\
(0.0505)\end{array}$ & $\begin{array}{c}0.0319 \\
(0.0736)\end{array}$ & $\begin{array}{c}0.0708 \\
(0.0510)\end{array}$ & $\begin{array}{c}0.0319 \\
(0.0746)\end{array}$ \\
\hline $\ln E X P$ & $\begin{array}{c}-0.0394^{\circ *} \\
(0.0115)\end{array}$ & $\begin{array}{c}-0.0542^{* *} \\
(0.0156)\end{array}$ & $\begin{array}{c}-0.0685^{\circ} \\
(0.0203)\end{array}$ & $\begin{array}{c}-0.0894^{\circ *} \\
(0.0251)\end{array}$ \\
\hline Adjusted $\mathrm{R}^{2}$ & 0.9732 & 0.5456 & 0.9727 & 0.5783 \\
\hline No. of Obs. & 312 & 192 & 312 & 192 \\
\hline
\end{tabular}

* (**) Indicates statistical significance at the five (one) percent level. Intercept dummy variables and instruments are analogous to Table 7. 

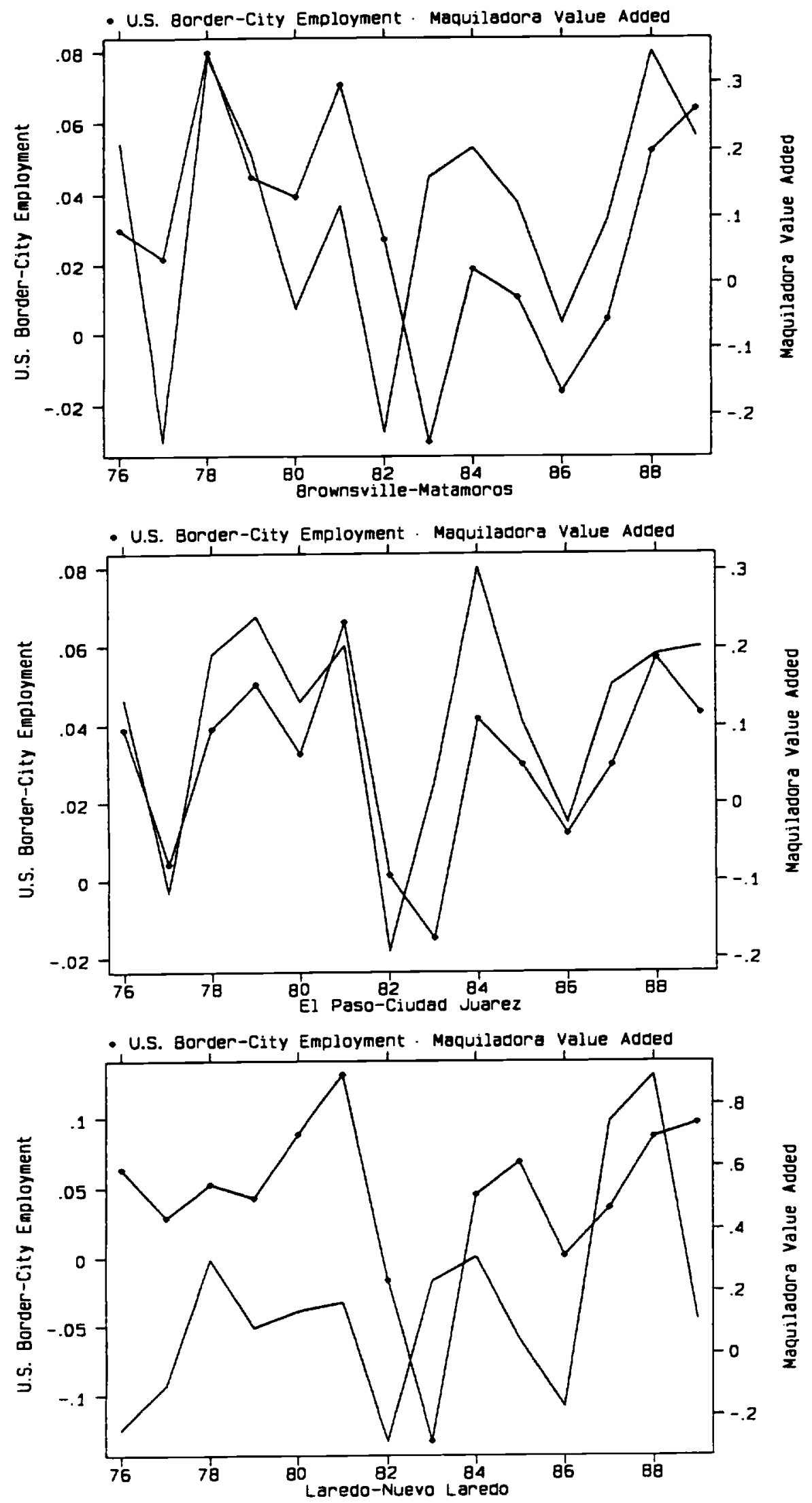

Figure 1a: Annual Growth in Border-City Pairs 

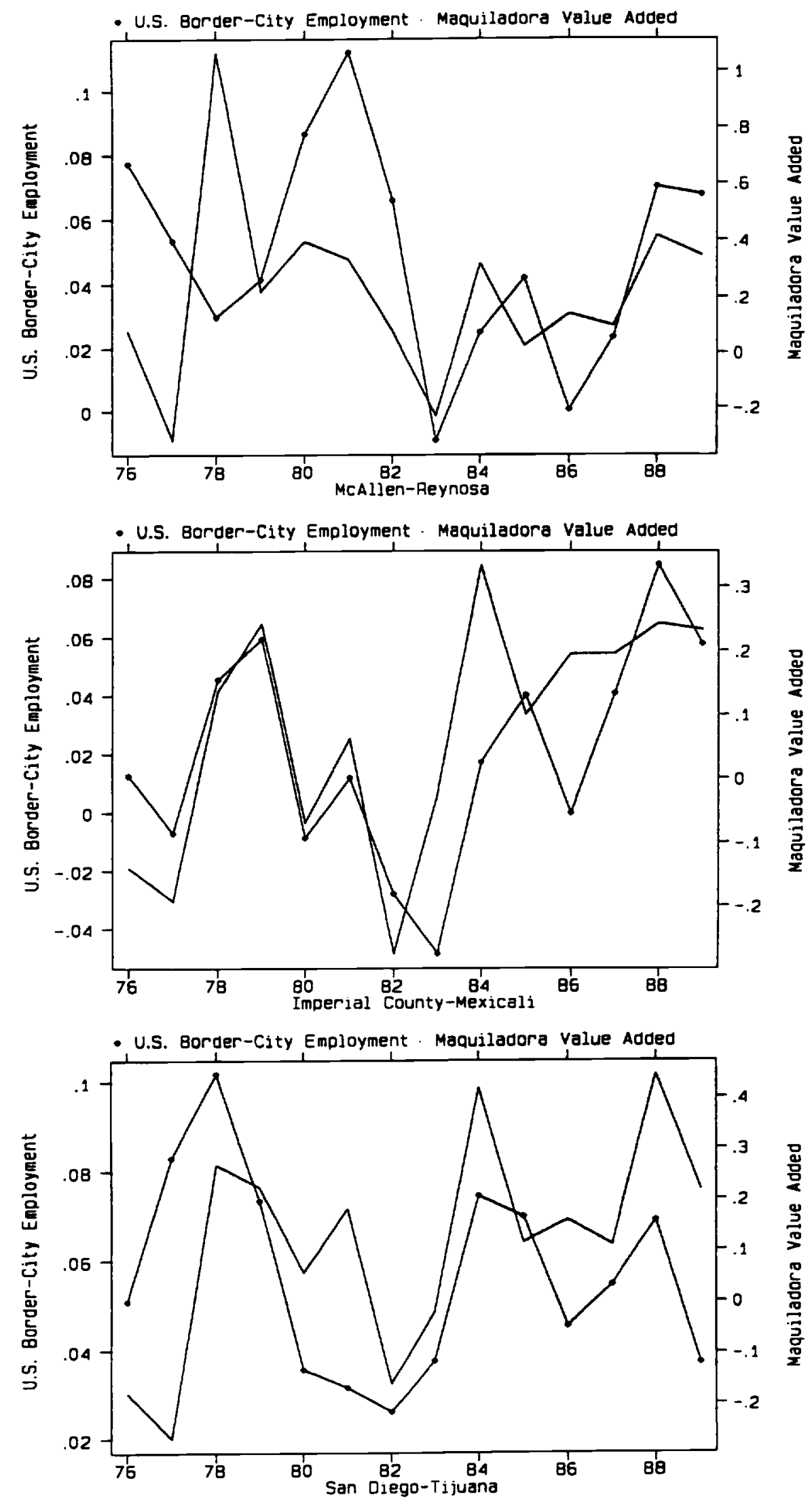

Figure 10: Annual Growth in Border-City Pairs 


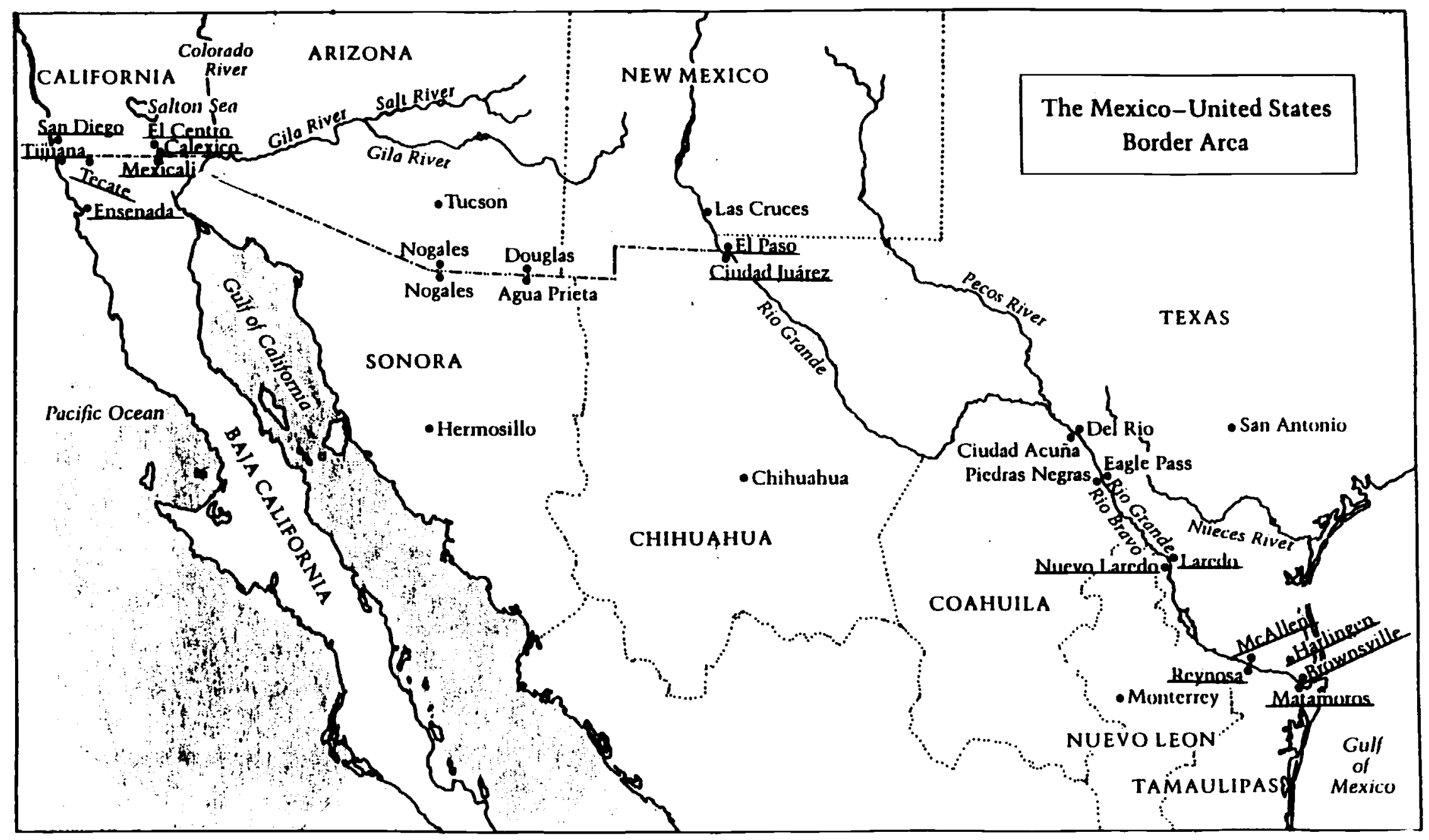

n 